$\underline{\text { Avicenna Journal of Nursing and Midwifery Care - ISSN 2676-5748 }}$

\title{
Psychometric Properties of Persian Version of Condensed Nurses' Occupational Stress Scale in Covid-19 Pandemic Period
}

\author{
Maryam Safari Shirazi ${ }^{*}$, Marziyeh Sadeghzadeh ${ }^{2}$, Moslem Abbasi ${ }^{2}$
}

1. Master Student, Department of general psychology in the Salman Farsi University, Kazeroon, Fars, Iran

2. Assistant Professor, Department of Psychology, Salman Farsi University, Kazeroon, Fars, Iran

\begin{tabular}{|c|c|}
\hline Article Info & ABSTRACT \\
\hline $\begin{array}{l}\text { Received: } 2021 / 02 / 02 \\
\text { Accepted: } 2021 / 04 / 22 \\
\text { Published Online: } 2021 / 09 / 21\end{array}$ & $\begin{array}{l}\text { Introduction: Nursing is recognized in all countries as a job with high occupational stress. } \\
\text { Therefore, the existence of tools to assess this occupational stress can contribute research into } \\
\text { nurses' mental health. The aim of this study was to investigate the psychometric properties of } \\
\text { Persian version of the Condensed Nurses' Occupational Stress Scale (NOSS). }\end{array}$ \\
\hline doi 10.30699 /ajnmc.29.3.245 & $\begin{array}{l}\text { Methods: In this cross-sectional study, } 224 \text { nurses working in two hospitals in Shiraz, Iran, } \\
\text { which were chosen as care centers for patients with coronavirus, were selected by convenience } \\
\text { sampling method and completed the Condensed Nurses' Occupational Stress Scale. SPSS } 22 \text { and } \\
\text { AMOS software were used to analyze the data. }\end{array}$ \\
\hline $\begin{array}{l}\text { Use your device to scan } \\
\text { and read the article online }\end{array}$ & $\begin{array}{l}\text { Results: The results of exploratory factor analysis using principal components method and } \\
\text { confirmatory factor analysis confirmed the two-factor structure of "stresses related to } \\
\text { environmental-organizational factors" and "stresses related to high workload' in the Persian } \\
\text { version of the Nurses' Occupational Stress Scale. In addition, Chronbach's alpha and McDonald } \\
\text { omega were used to determine internal consistency, Chronbach's alpha and McDonald's omega } \\
\text { coefficients for the whole scale }(\alpha: 0.94 \text { and } \omega: 0.95) \text { and two subscales of "stresses related to } \\
\text { environmental-organizational factors" ( } \alpha: 0.91 \text { and } \omega: 0.91) \text { and "Stresses related to high } \\
\text { workload" }(\alpha: 0.90 \text { and } \omega: 0.91) \text { were within acceptable limits. }\end{array}$ \\
\hline
\end{tabular}

Conclusion: Condensed Nurses' Occupational Stress Scale has acceptable psychometric properties in Iranian society and can be used as a useful tool in research related to nurses' occupational stress.

Keywords: COVID-19 Pandemic, Occupational stress, Reliability, Nurses, Validity

Corresponding Information:

Maryam Safari Shirazi, Master Student, Department of general psychology in the Salman Farsi University, Kazeroon, Fars, Iran. Email: maryam.safaree@gmail.com

Copyright $@$ (2021, This is an original open-access article distributed under the terms of the Creative Commons Attribution-noncommercial 4.0 International License which permits copy and redistribution of the material just in noncommercial usages with proper citation.

How to Cite This Article:

Safari Shirazi M, Sadeghzadeh M, Abbasi M. Psychometric Properties of Persian Version of Condensed Nurses' Occupational Stress Scale in Covid-19 Pandemic Period. Avicenna J Nurs Midwifery Care. 2021; 29 (3) :245-255 
بررسى ويثَى هاى روانسنجى نسخة فارسى فرم كو تاه مقياس استرس شغلى يرستاران در دورة همدَيرى كوويد-19

\section{مريم صفرى شيرازى"'، مرضيه صادقزاده'، مسلم عباسى}

$$
\begin{aligned}
& \text { 1. ا.نشجوى كارشناسى ارشد، كروه روانشناسى عمومى، دانشكاه سلمان فارسى، كازرون، فارس، ايران }
\end{aligned}
$$

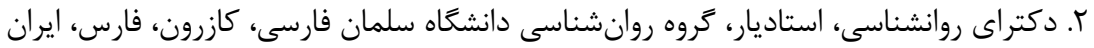

\begin{tabular}{|c|c|}
\hline جكيده & اطلاعات مقاله \\
\hline 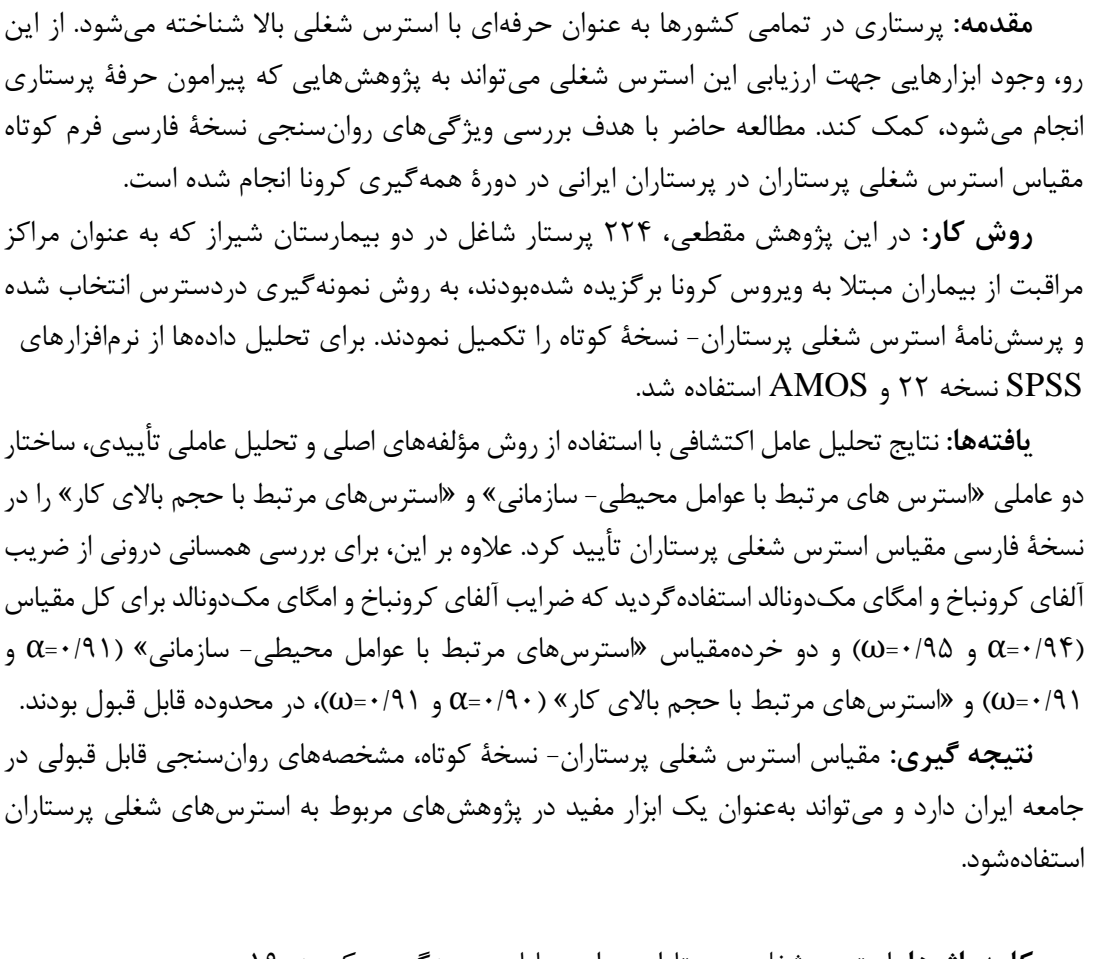 & 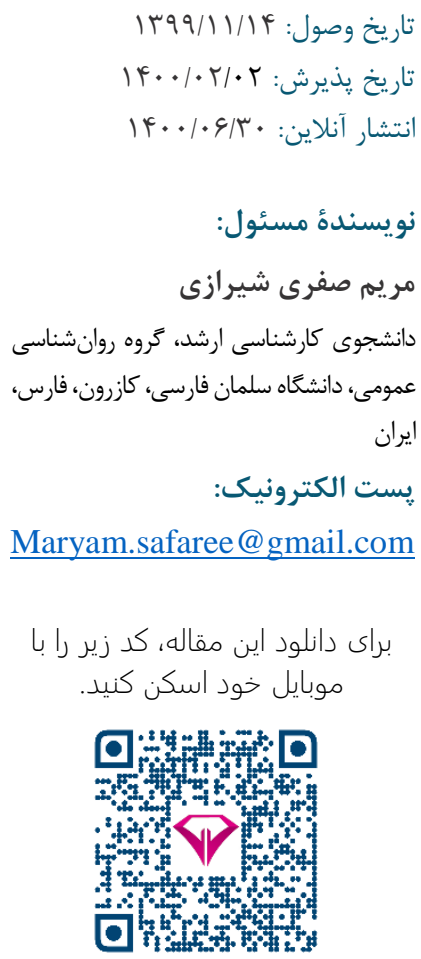 \\
\hline
\end{tabular}

عوامل استرسزاى مربوط به كار أF/D ميليارد دلار در سال تخمين زدهده است [ب] در واقع استرس شغلى يك واكنش جسمى ود عاطده استى مضر

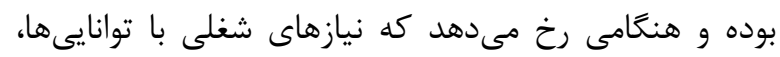
منابع، دانش يا نيازهاى فرد مطابقت نداشته باشد. البته اين

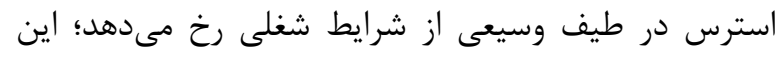

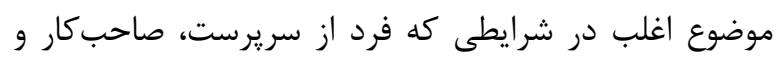
همكاران حمايت كافى دريافت نكرده يا كنترل كمى بر روند

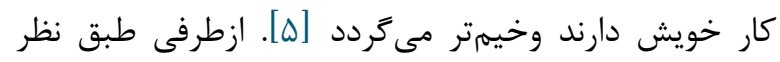

براساس اسناد منتشرشده از سوى سازمان بينالمللى كار،

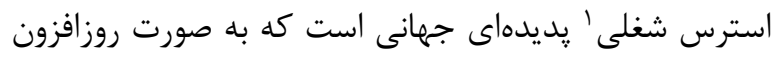

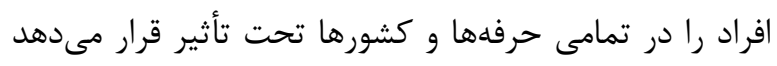

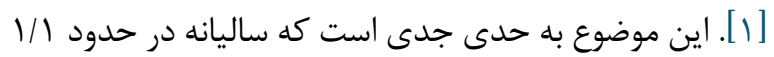

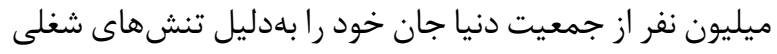

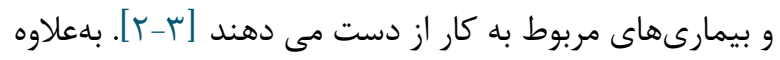

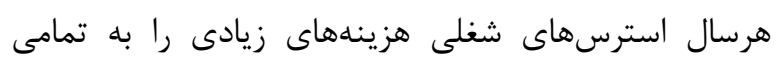
دولتها تحميل مىسازد. جنانكه در دهلهاى اخير هزينه

'Occupational Stress 
بيمارىهاى قلبى-عروقى و دردهاى اسكلتى- عضلانى است

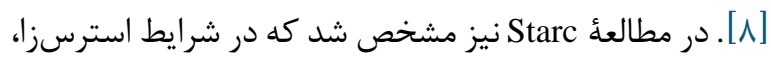

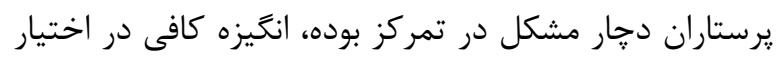

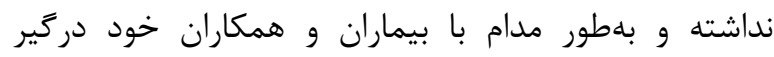

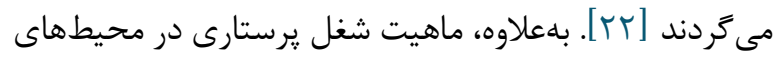
كارى سخت، ساعات طولانى كار، شيفت كارى شب و ونارئ اضافهكارى زياد، تعارض بين نقشهاى كارى كارى و ارتباط مستقيم با افراد رنجكشيده و حتى مركى بيماران مواردى هستند كه به به نيه

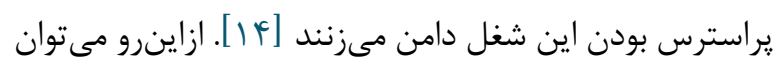

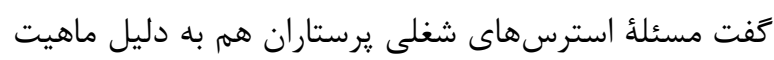

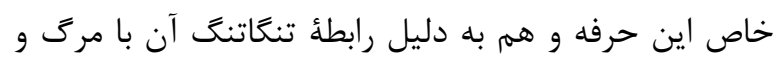

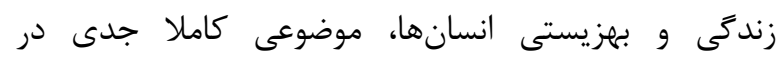

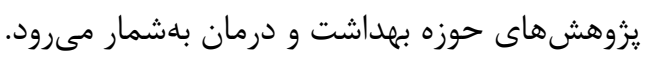

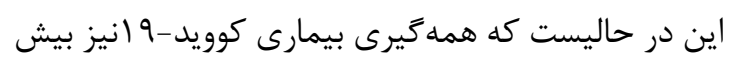

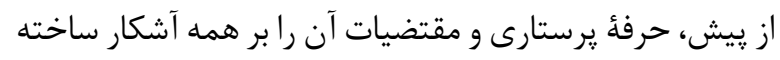

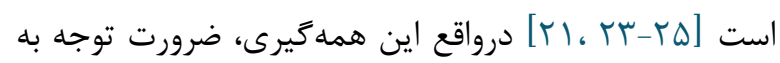

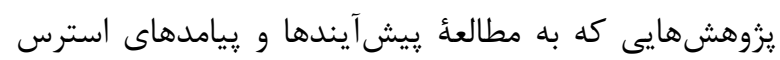

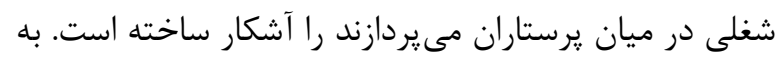
عبارت ديخر با قرار كرفتن نظام سلامت در خط مقدم مبرد مبارزه

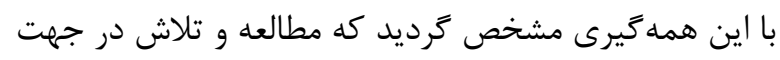

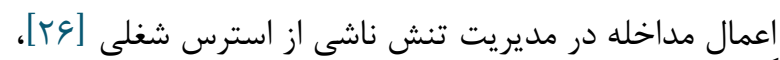

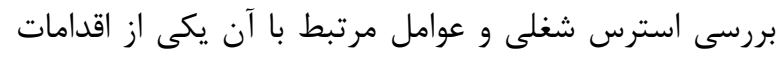
مهمى است كه بايد به صورت كاملا ضرورى توسط تمامى نيى

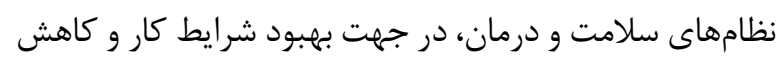

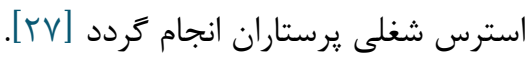

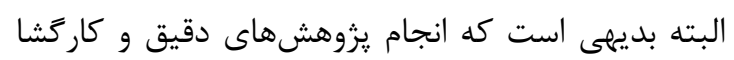

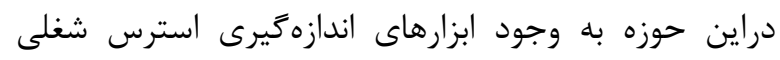

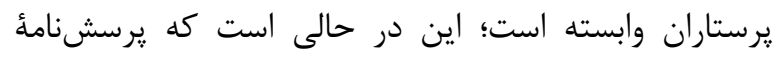

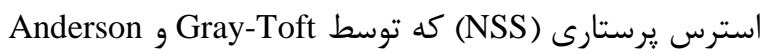

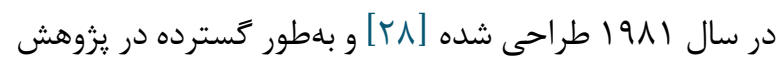

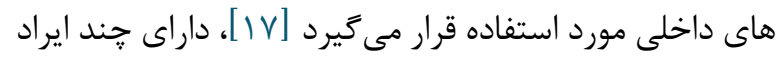

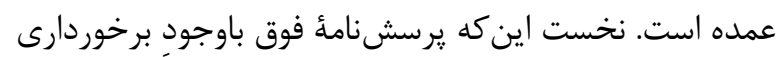

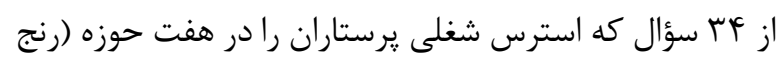

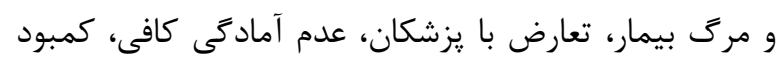

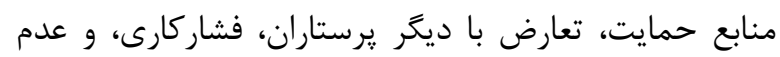

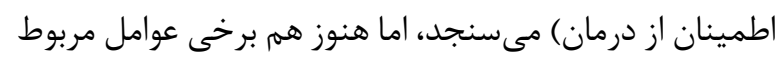

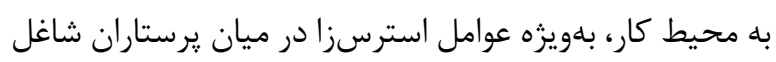

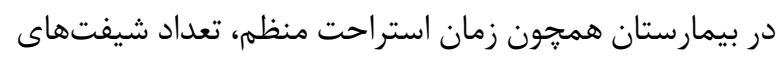

Sharit و Salvendy مسئوليتهايى كه بالاتر يا پايينتر از

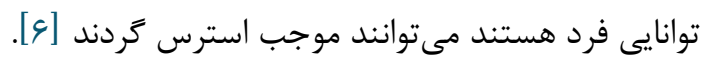

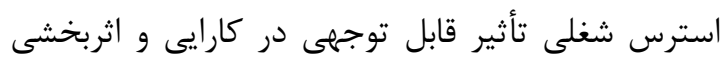
كار كنان دارد؛ بهويزه استرس شغلي تجربه تائشده توسط كاركنان

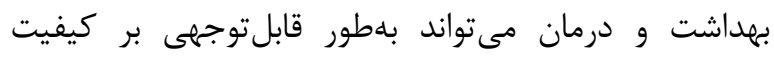

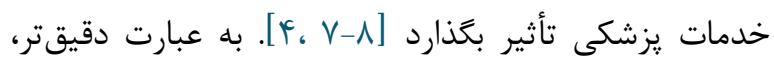

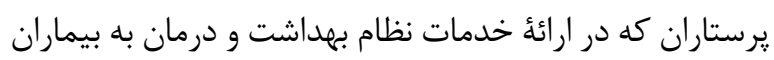

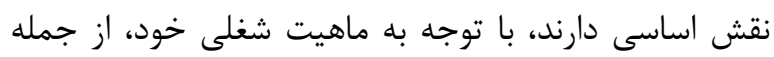

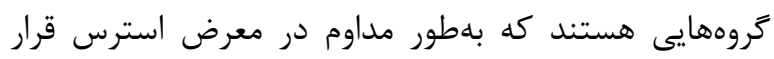
مى گيرند [9]

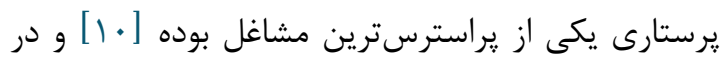

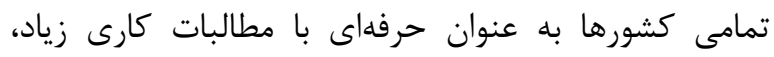

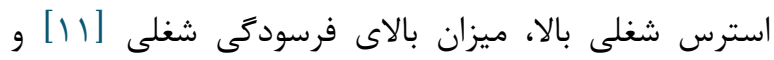

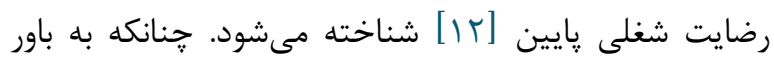

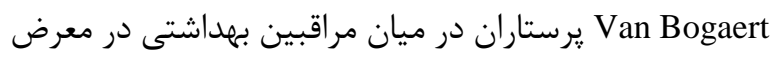

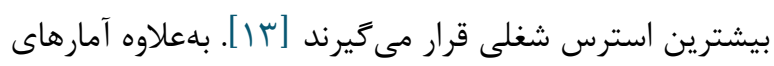

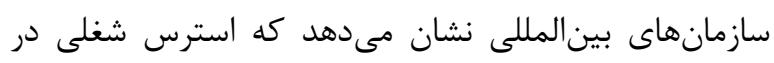

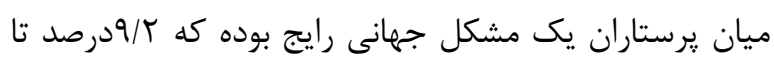

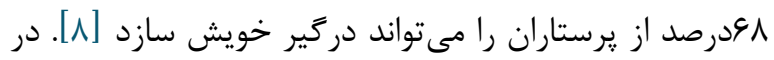

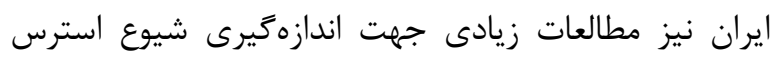

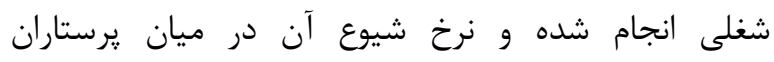

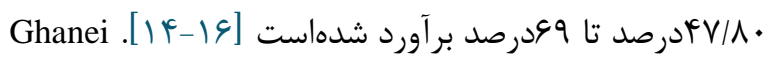
و همكاران شيوع استرس شغلى در برستاران ايرانى را بهطور

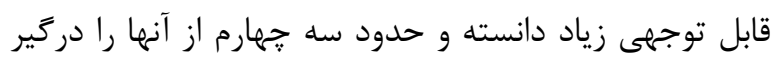

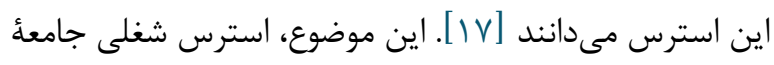

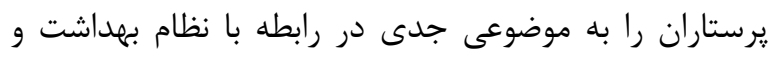

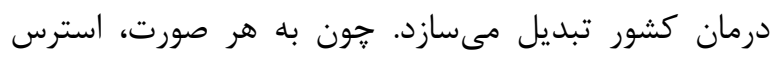

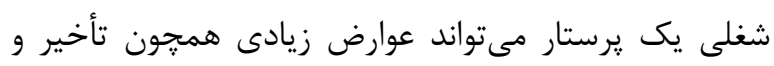

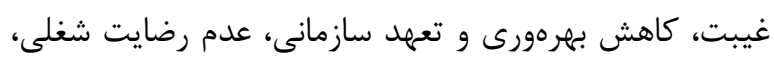

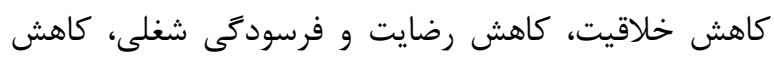

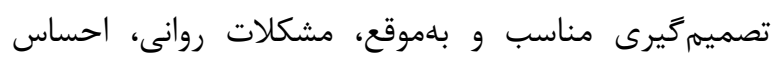

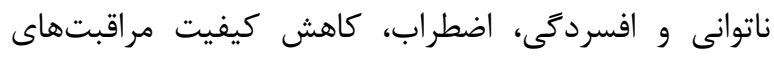

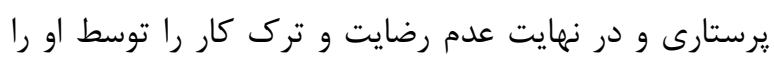

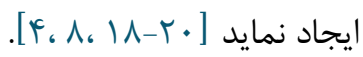

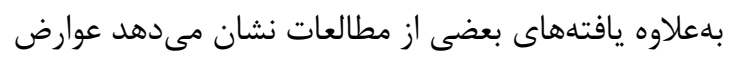

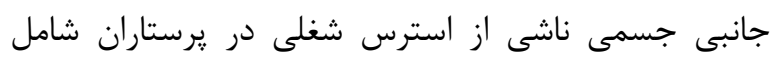

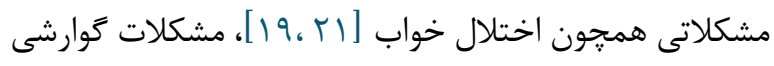

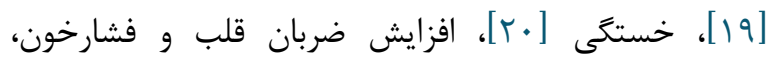


داده يرت تكمتغيرى شناخته و حذف گرديد و اطلاعات

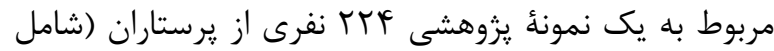
ه ه مرد و 199 ز زن) در فرايند تحليل شركت داده شد. ابزار

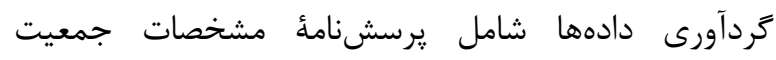
شناختى و مقياس استرس شغلى يرستاران- نسخهُ كوتاهّ بود.

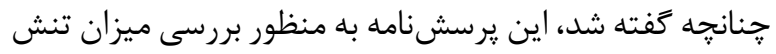

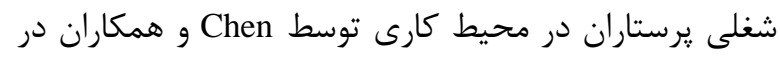

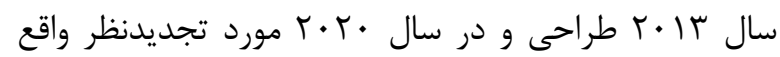

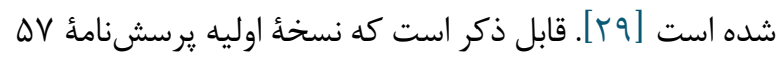

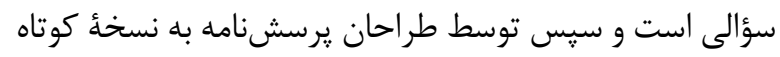

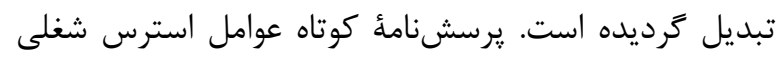

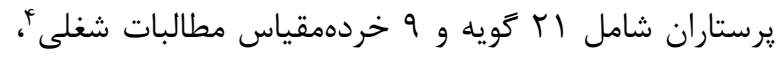

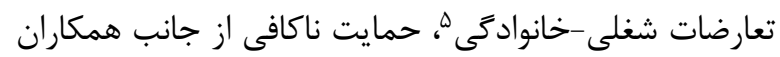

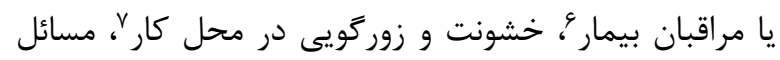

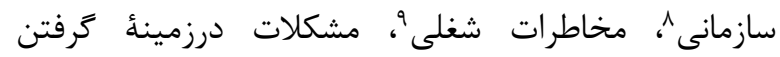

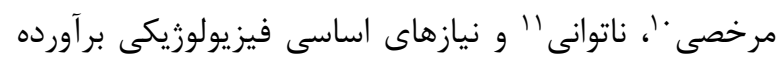

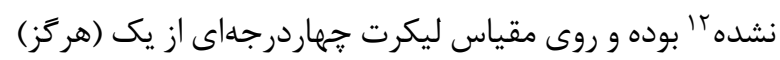

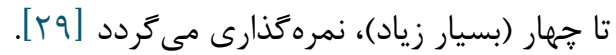

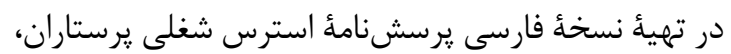

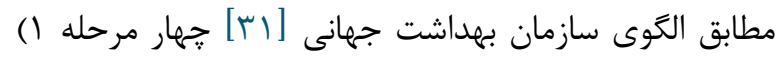

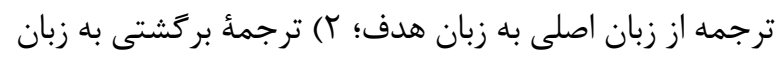

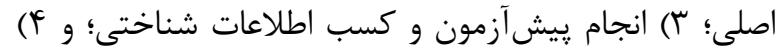

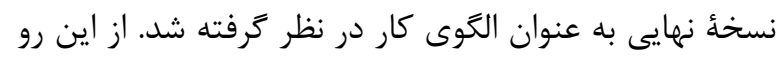

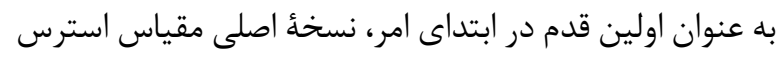
شغلى برستاران توسط دو نفر مسلط به هر دو زبان انخليسى و

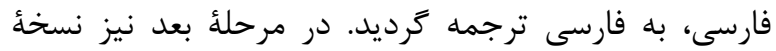

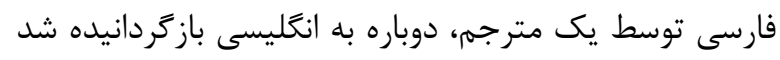
و عبارات ترجمه شده توسط يكى از اساتيد زبان انكليسى با دان

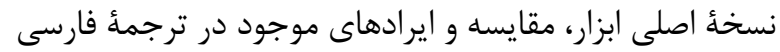

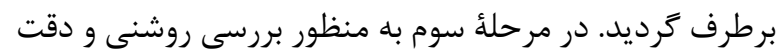

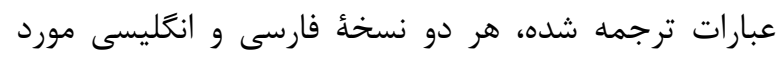
بازبينى و اصلاح دو نفر از اساتيد روانشناسى دانشكاه قرار

${ }^{\vee}$ Workplace Violence and Bullying

^Organizational Issues

' Occupational Hazards

- Difficulty Taking Leave

' Powerlessness

" Unmet Basic Physiological Needs
آنكال و دريافتى اضافه كار يرستارى، مسائل مربوط به گَرفتن

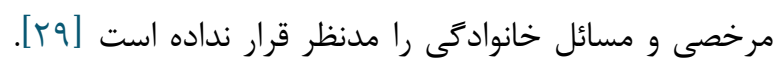

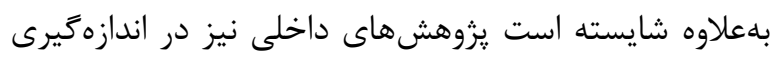

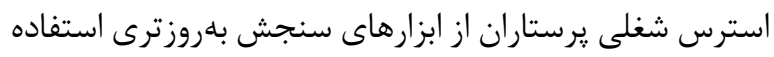

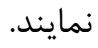
با توجه به مواردى كه عنوان گرديد، هدف از يزوهش حاضر بررسى نسخة فارسى يرسشنامة جديدترى است كه جهت اندازهخيرى استرس شغلى برستاران طراحى گرديده است. اين برست

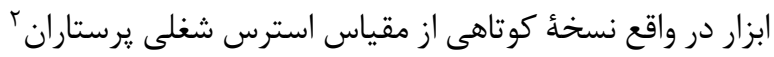

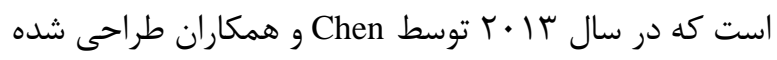

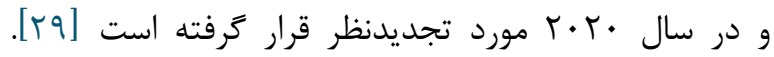

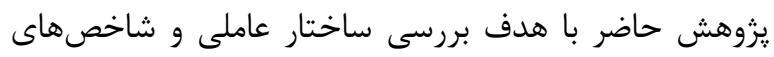
روانسنجى مقياس استرس شغلى يرستاران - نسخئ كوتاه در بين يرستاران ايرانى در دوران همه كيرى كرونا است.

\section{روش كار}

اين مطالعه مقطعى در سال 99 ا آدر شهر شيراز انجام

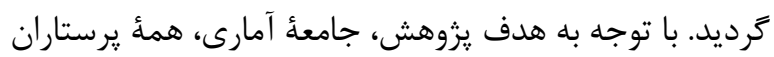

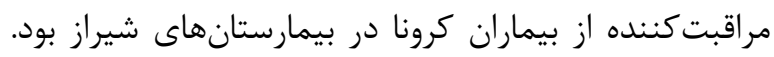

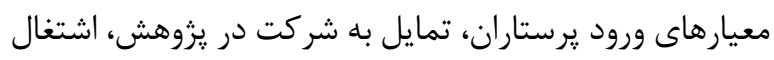

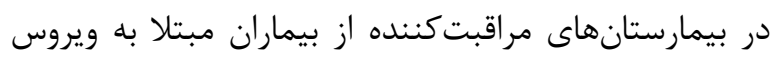

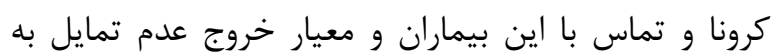
شركت در يزوهش درنظر ترفته شد.

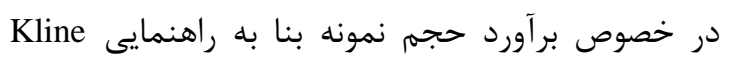
حداقل حجم نمونه در يزوهشهايى كه از مدليابى معادلات

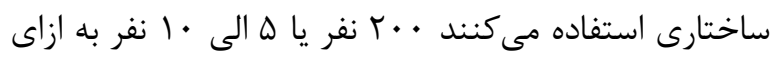

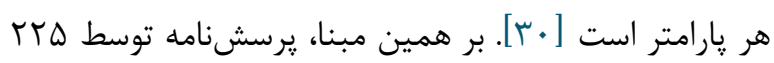

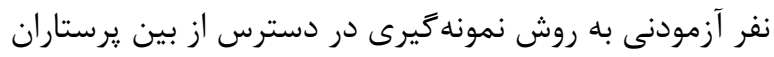

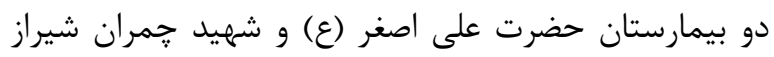

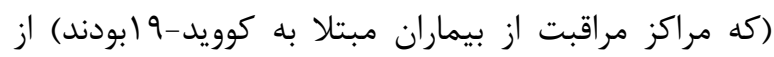

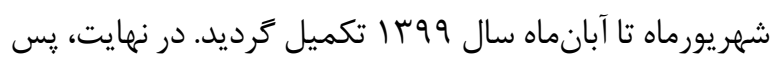

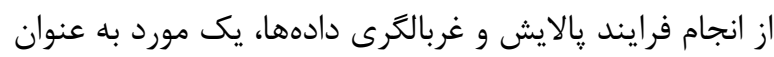

' Nurses Occupational Stress Scale: NOSS ${ }^{r}$ Condensed nurses occupational stress scale $=$ condensed NOSS

"Work Demands - Work-Family Conflict 'Insufficient Support from Coworkers or Caregivers 
آزمون كرويت بارتلت نيز با مقدار وس 19 • در سطح ا | • • • معنىدار است. اين دو شاخص مطابق نظر Gamst ،Meyers

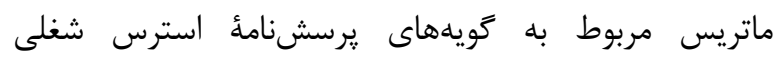

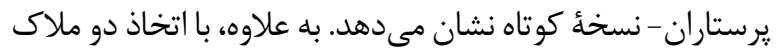
مقدار ويزٔه بيشتر از يك و منحنى صخرهاى، وجود دو مؤلفه در

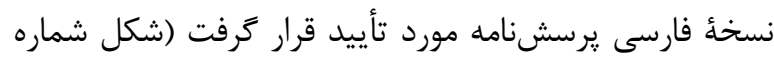

قابل ذكر است كه در فرايند تحليلعاملى انجام گرفته يك Fويه به دليل بارعاملى كمتر از • \&/• حذف گرديد و فرايند تحليل با گويههاى بهجامانده ادامه يافت. بدين ترتيب دو مؤلفه

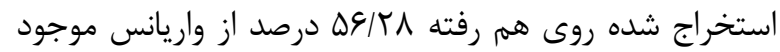

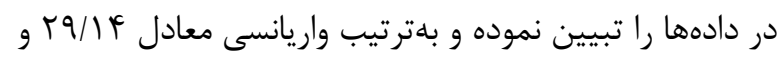
FV/ IF به گويههاى مشخصَٔ آنها با عامل شناسايى شده در بروهش و همكاران كه 9 عامل را برآورد كردهبودند مطابقت نداشته و در نتيجه عامل يك و دو به ترتيب لاسترسهاى مرتبط

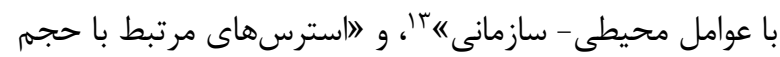

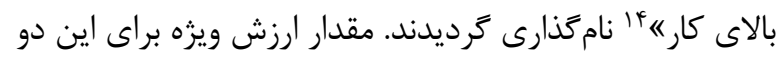

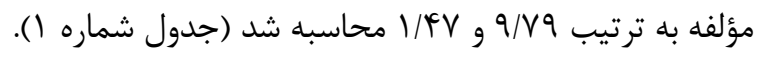

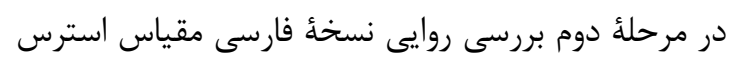

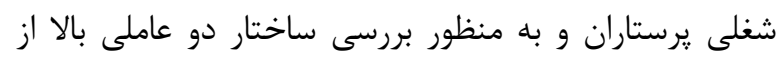

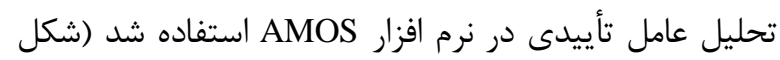

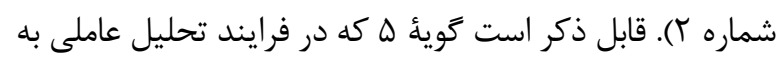
شيوه مؤلفههاى اصلى به دليل بار عاملى پايين حذف گرديده

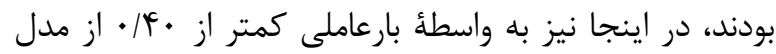
ساختارى حذف گرديد. براى بررسى برازش الگوى دو عاملى موجود در يرسشنامٔ

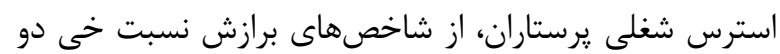
به درجه آزادى ( برازش تطبيقى (CFI)، شاخص نيكويى برازش (GFI)، (GFI) و واريانس

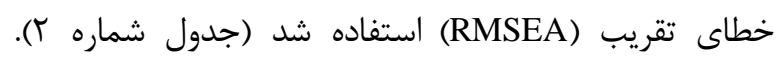
جنانكه در اين جدول مشاهده مىشود تمامى شاخصهاى فوق از مقادير مطلوبى برخوردار هستند.

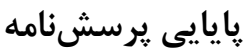

Is Stresses related to high workload
گرفت. همجنين جهت تعيين روايى محتواى كمى به شيوء لاوشه از نظر سه نفر از متخصصان روانشناسى و سه متخصص

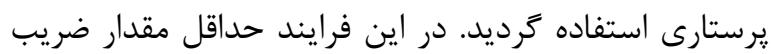

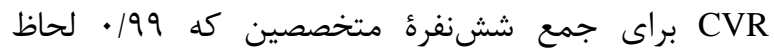
مى گردد، به دست آمده است. به علاوه در اين مرحله روايى صورى يرسشنامه نيز با نظر متخصصان روانشناسى بررسى شد و با توجه به وجود برخى ابهام در عبارات و نيز رعايت تناسب تغييراتى در يكى از گويهها اعمال گر ديد. يس از دريافت كد اخلاق و مجوز انجام يزوهش از دانئ دانشعاه علوم يزشكى شيراز و بيمارستانهاى حضرت على اصغر (ع) و

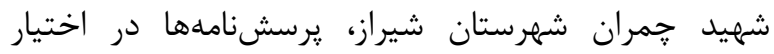
يرستاران قرار گرفت. لازم به ذكر است كه يرسشنامه بهان براساس معيارهاى ورود در اختيار شركت كنندگان قراركرفت و به آنها اطمينان داده شد كه اطلاعات كاملاً محرمانه خواهد ماند و نتايج به صورت گروهى و آمارى و نه به صورت فردى منتشر خواهد شد. در يثوهش حاضر براى بررسى روايى سازه يرسشنامهُ

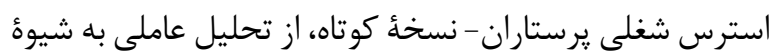
مؤلفههاى اصلى و تحليل عاملى تأييدى استفاده شد. همجنين يُّن ضريب آلفاى كرونباخ و امغاى مكدونالد جهت بروسى همسانى درونى، مورد استفاده قرارگرفت.

\section{يافته ها}

در مطالعئ حاضر مجموعاً FT نفر از يرستاران شاغل در دو بيمارستان حضرت على اصغر (ع) و شهيد جمران شيراز به مجه عنوان شركت كننده مورد بررسى قرارگرفتند. از ميان يرستاران شركت كننده در يزوهش VD/F درصد زن و و

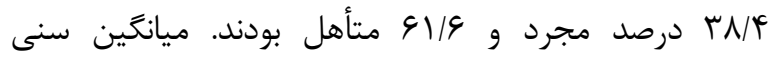

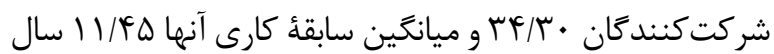

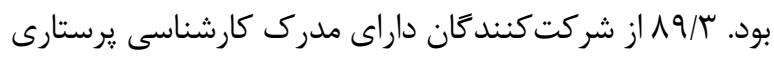
و • • ا درصد مدرك كارشناسى ارشد يرستارى داشتند.

\section{روايى سازه}

جهت بررسى روايى نسخهُ فارسى كوتاه استرس شغلى نه يرستاران نخست تحليل عاملى به شيوه مؤلفه هاى اصلى با جرخش واريماكس مستقيهم انجام گرديد. نتايج اين تحليل نشان

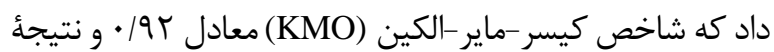

${ }^{1 T}$ Stresses related to environmental-organizational factors 


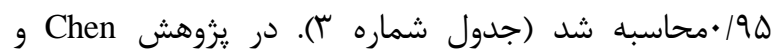
همكاران مقادير ضريب آلفا براى خردهمقياسهاى مطالبات

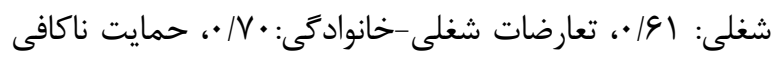

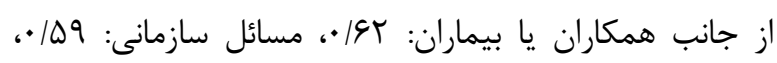
مخاطرات شغلى: qس/.، مشكلات درزمينهُ گرفتن مرخصى: /VV

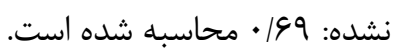

جهت بررسى همسانى درونى خردهمقياس هاى يرسشنامئ استرس شغلى يرستاران از محاسبه آلفاى كرونباخ و امگاى مكدونالد استفاده شد. مقدار ضريب آلفاى كرونباخ براى دو دوراسي

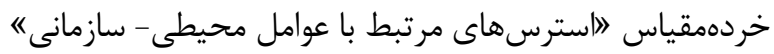
و 》استرسهاى مرتبط با حجم بالاى كاره به ترتيب 191 • • و و

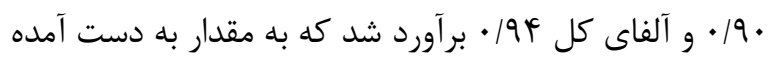
آلفاى كرونباخ در يرسشنامئ اصلى (1914 • •) شباهت دارد.

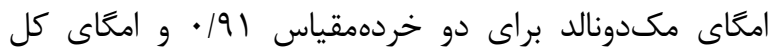

\section{Scree Plot}

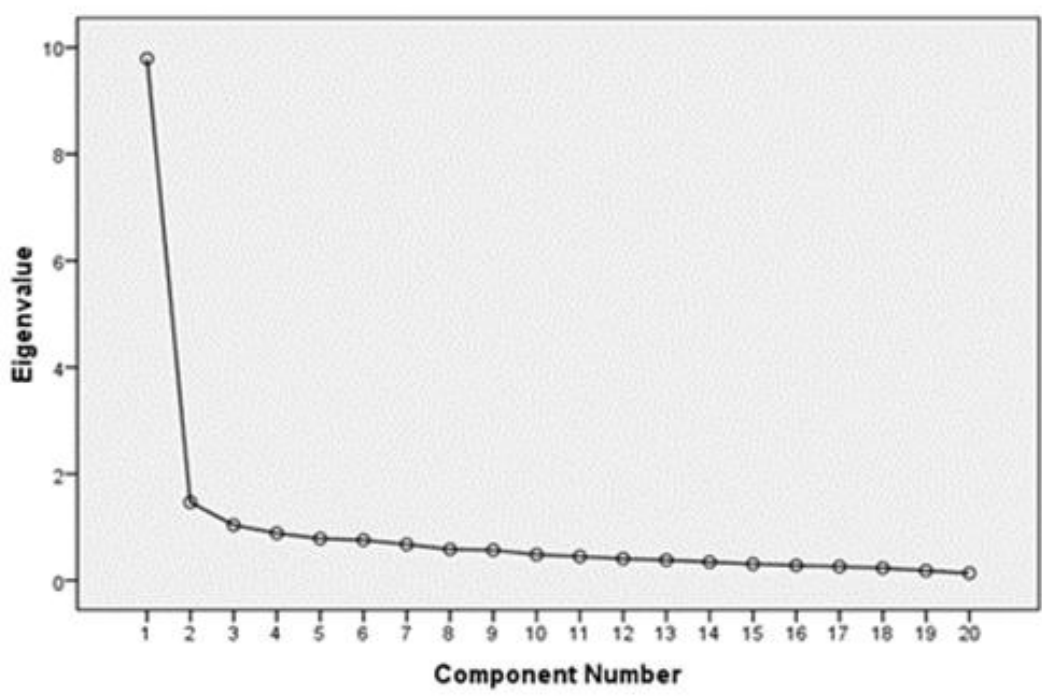

شكل ا. نمودار منحنى صخرهاى مربوط به تحليل عاملى نسخد فارسى فرم كوتاه يرسش نامةٔ استرس شغلى يرستاران (NOSS)

جدول ا. بار عاملى كَويههاى نسخةٌ فارسى فرم كوتاه يرسشنامهُ استرس شغلى پرستاران (NOSS)

\section{عامل عاملدوم}

كَويه ها

$$
\text { عامل ا: استرسهاى مرتبط با عوامل محيطى - سازمانى }
$$

(Stresses related to environmental-organizational factors)

.$/ 09$

$\cdot / V Y$

$\cdot / V T$

$\cdot / \mathrm{r} \cdot$

$\cdot / \mathrm{VH}$

$\cdot 194$

.$/ 94$

$\cdot / \mathrm{VV}$

$\cdot 194$

$\cdot / \Delta \mathrm{V}$
צ. ناجارم برنامه فعاليتها يا سفر هاى خانوادكى را با مسئوليتهاى شغلى ام مطابقت دهم.

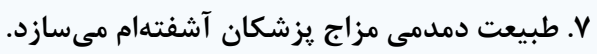

^. نگَرانم كه بى كفايتى برخى از همكاران بر سلامتى بيماران اثر بحذارد.

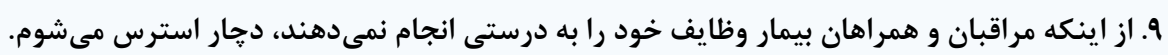

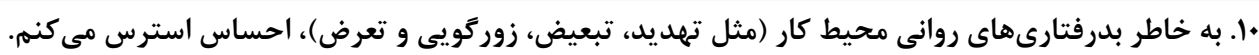

ال. آنكال بودن زندكيم را تحت تاثير قرار مىدهد

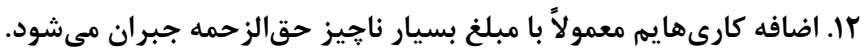

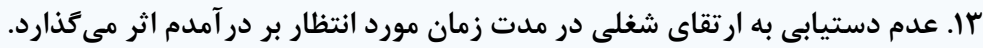

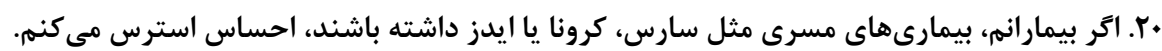

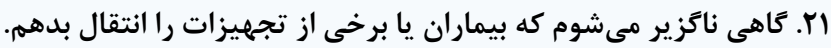




\section{عامل اول عاملدوم}

كويه ها

عامل r: استرسهاى مرتبط با حجم بالاى كار (Stresses related to high workload)

- $/ Q F$

$\cdot \mid \mathrm{VI}$

- 194

$\cdot 19$.

. $19 \mathrm{~T}$

$\cdot|9|$

$\cdot 10 \Delta$

$\cdot / Y^{F}$

$\cdot / V V$

$\cdot / \wedge \mathrm{V}$

$I / F V$

TV/IF
ا. بايد عواطف و احساسات منفى بيماران يا خويشاوندان آنها را تحمل كنم.

r. وظايف بيش از حد در محيط كار مانع كمك و توجه من به بيماران مى بـود.

r. به خاطر شرايط كارى بيمارستان، ناجارم در واحدهايى به جز تخصص خودم نيز حاضر شوم.

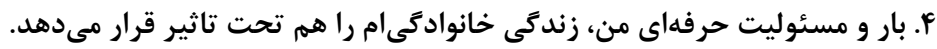

If

ها. حتى در سخت ترين شرايط هم نمى توانم ناراحتى شديدم را براى معافيت از كار بهانه كنم.

19. اتر شرايط بيمارم بهتر نشود، احساس ناراحتى مئى كنم.

VI. در ساعات كارى، براى مراقبت از سلامت روانى بيمارانم زمان كافى در اختيار ندارم.

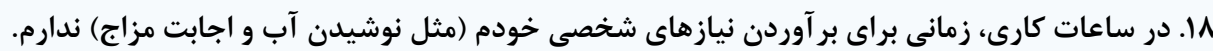

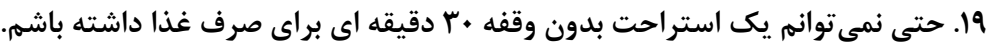

$9 / 79$

مقدار ويثره

واريانستبيينشده توسطعامل

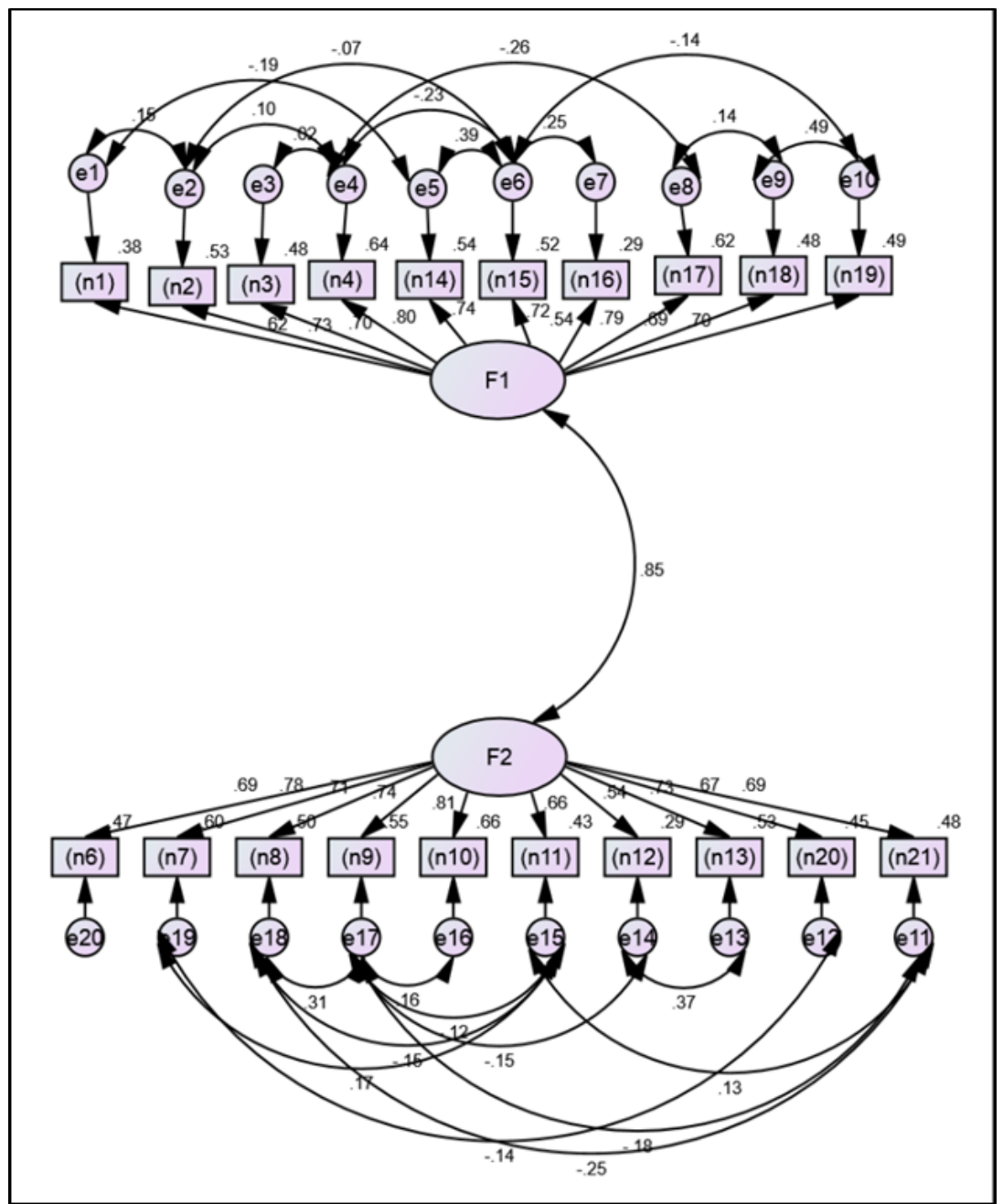

شكل r - ساختار عاملى مربوط به نسخئ فارسى فرم كوتاه پِرسشنامهُ استرس شغلى پرستاران 
جدول r. شاخصهاى نيكويى برازش در تحليلعاملى تأييدى

\begin{tabular}{|c|c|}
\hline مقدارقابلقبول & مقدار \\
\hline$<r$ & $T / \cdot T$ \\
\hline$<\cdot / \cdot v$ & .1 .9 \\
\hline$>\cdot 190$ & .199 \\
\hline$>\cdot 190$ & .199 \\
\hline$>\cdot 190$ & .199 \\
\hline$>\cdot / 90$ & .190 \\
\hline
\end{tabular}

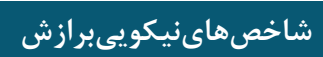

نسبت مجذورخى بر درجهآزادى (chi-square/df)

واريانس خطاى تقريب (RMSEA)

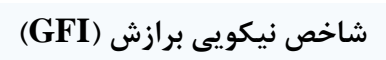

شاخص برازش تطبيقى (CFI) شاخص نيكوب برازش (IFI)

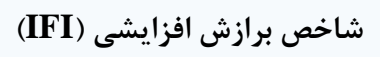

شاخص برازش هنجار شده (NFI)

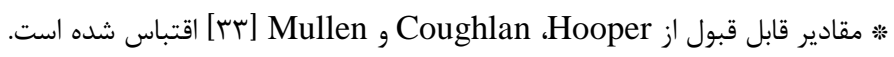

جدول ب. يا يايى نسخئ فارسى فرم كوتاه استرس شغلى يرستاران

\begin{tabular}{|c|c|c|c|c|}
\hline امعاى مكدونالد & حجم & تعداد كويه ها & مقدار آلفا & خرده مقياس \\
\hline .191 & TrT & 1. &.$/ 91$ & استرسهاى مرتبط با عوامل محيطى - سازمانى \\
\hline .191 & TrT & 1. & $\cdot / 9$. & استرسهاى مرتبط با حجم بالاى كار \\
\hline.$/ 9 \Delta$ & $r$ r. & $r$. & .194 & كل \\
\hline
\end{tabular}

بحث

اختصاص يافته به بيماران كرونايى انجام گرفته، يك ساختار دو

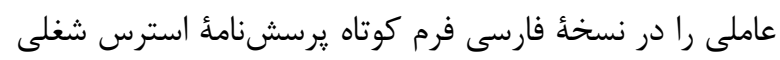

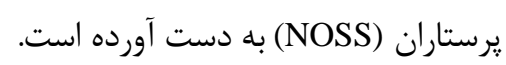

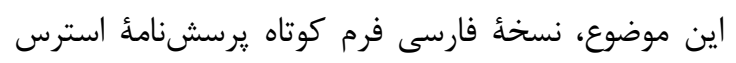
شغلى يرستاران را در مقايسه با نسخهُ اصلى آن تا حدى متمايز

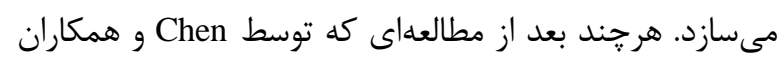

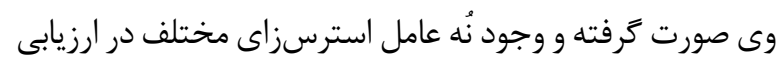
اين يرسشنامه از زندىى حرفهاى يرستاران را مورد تأكيد قرار مى دهد، يزوهش هايى همجون Xiang و همكاران [ra

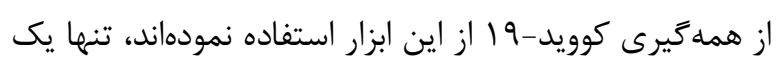
نمره كلى از استرس شغلى يرستاران را استخراج نموده و به به بررسى مجدد ساختار عاملى آن اقدام ننمودهاند. با اين همه هردو ئنس

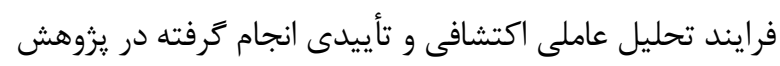

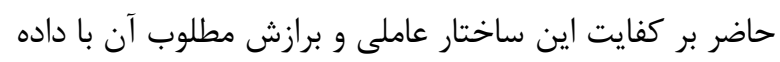
ها تأكيد مى كنند. به هر حال شايد در تبيين جرايى اين ساختار

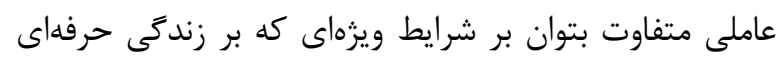

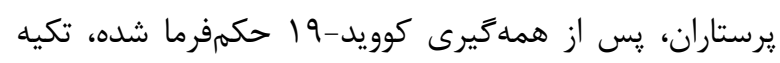

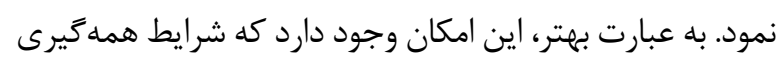

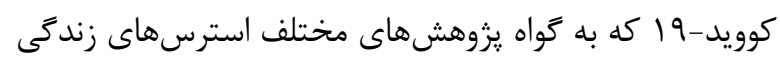
حرفهاى يرستاران را دستخوش تغيير و تحولى بىسابقه نموده

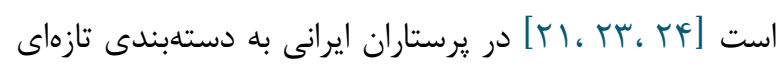

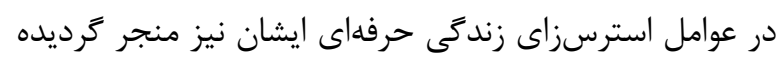

هدف از يزوهش حاضر بررسى ساختار عاملى و شاخصهاى روانسنجى فرم كوتاه مقياس استرس شغلى يرستاران (NOSS)

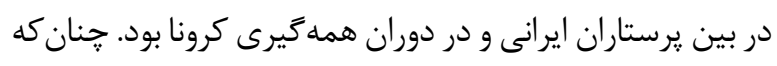

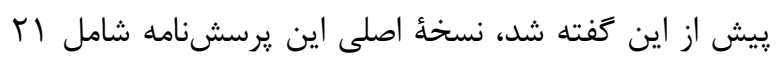

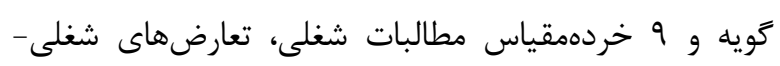
خانوادگى، حمايت ناكافى از جانب همكاران يا مراقبين بيمار،

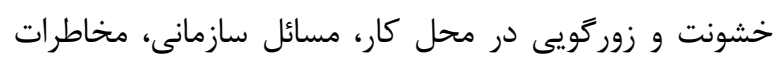
شغلى، مشكلات درزمينه گرفتن مرخصى، ناتوانى و نيازهاى

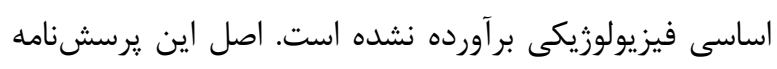
توسط Chen و همكاران در سال با • ب طراحى گرديد، و فرم

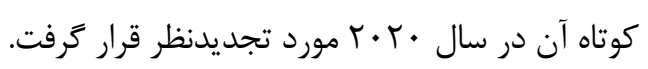

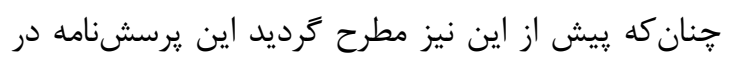

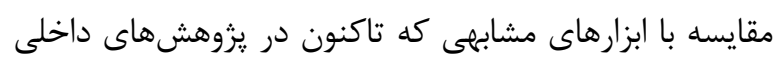
جهت اندازهخيرى استرس شغلى يرستاران قرار گرفته، داراى دو نقطهقوت مهمم است. نخست اين كه با تعداد گويههاى كمتر،

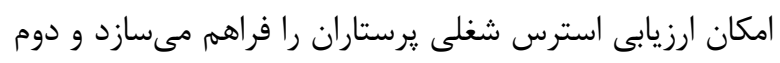
آنكه طيف گستردهترى از دغدغههاى شغلى روزمره پيرستاران همجون بهرهمندى يا عدم برخوردارى از زمان استراحت منظهم،

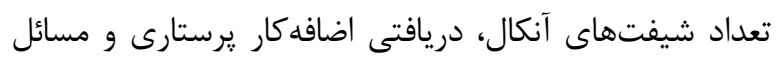
مربوط به گرفتن مرخصى را نيز مدّنظر قرار داده است. هرجند بايستى به خاطر داشت كه يافتههاى يزوهش به حاضر كه در زمر زمان

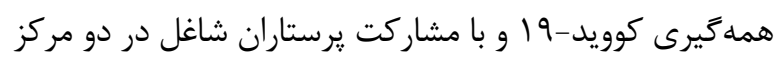


به ويروس كرونا مشغول به كار هستند. ازاينرو عدم بررسى روايى هم گرا و واگراى نسخةٌ فارسى استرس شغلى يرستاران

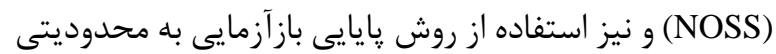
براى يزوهش حاضر تبديل شدهاست. بنابراين با توجه به ميزان

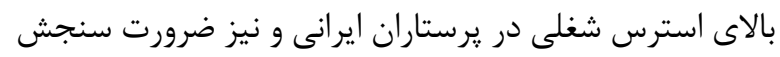
دقيق ميزان استرس شغلى و اقدامات موثر براى كاهش تنش

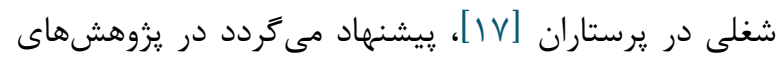

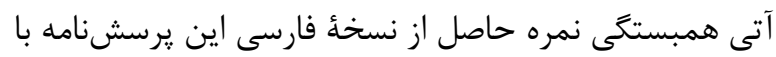
نمرات سازههاى مطرح ديخر در حوزه پيرستارى مورد توجه

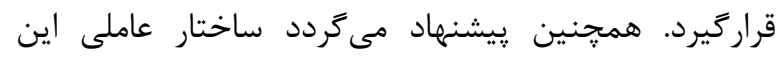
يرسشنامه يس از يايان همهَيرى ويروس كرونا و در بين يرستارانى كه در اين مدت بهطور مستقيم در تعامل با بيماران كرونايى قرار نداشتهاند نيز مورد مطالعه قرار گيرد.

\section{سياسخزارى}

از همةٔ يرستاران شاغل در بيمارستان حضرت على اصغر

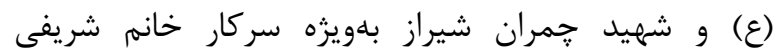
كارشناس واحد توسعهُ آموزش بالينى بيمارستان شهيد جمران

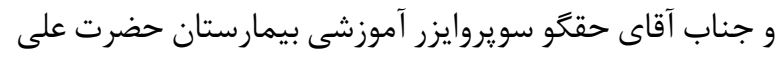

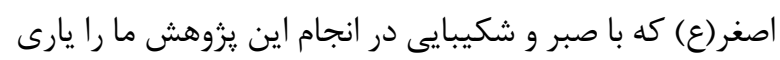
نمودند صميمانه سياس گزارى مىنماييم. قابل ذكر است كه

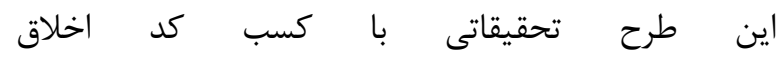
(IR.IAU.KAU.REC.1399.051) يزوهشهاى زيستيزشكى دانشعاه آزاد اسلامى كازرون انجام كرفته است.

$$
\text { تعارض در منافع }
$$

بين نويسند

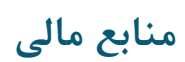

منابع مالى اين مطالعه توسط نويسندكان تأمين شده است.

\section{References}

1. International Labor Organization. Occupational Stress and Stress Prevention in Specific Occupations. [Accessed on 3 January 2020]. Available from: https://www.ilo.org/safework/areasofwork/workp lace-health-promotion-and-wellbeing/WCMS_250122/lang--en/index.htm.
باشد. اين دستاهندى تازه مىتواند دليلى براى ساختار دوعاملى فرم كوتاه يرسشنامة استرس شغلى يرستاران در يزوهش حاضر

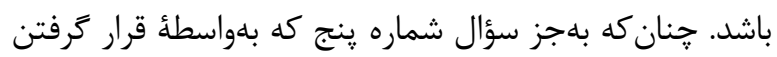

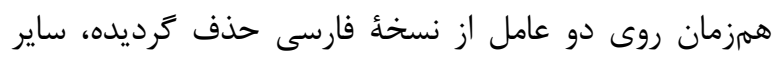
كويههاى مريوط به اين :رسشنامه در يك آرايش دوعاملى در

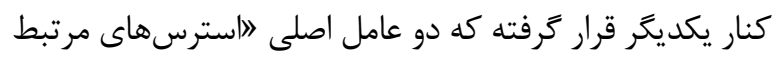
با عوامل محيطى-سازمانى" و \استرسهاى مرتبط با حجم بالاى كار" را تشكيل دادهاند. به كلام ديخر شايد بتوان كفت در بين زيرستاران دادهان ايرانى كه در ماههاى گذشته و درطى همه گيرى ويروس كرونا به يرستارى از مبتلايان به اين بيمارى مشغول بودهاند، تمايز ميان منابع مختلف استرس شغلى از بين رفته و منجر به ادراك اين استرس در قالب دو عامل كلى گرديدهاست. به هرحال براساس يافتههاى

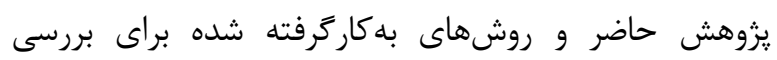
همسانى درونى كل مقياس و دو خردهمقياس مربوط به آن

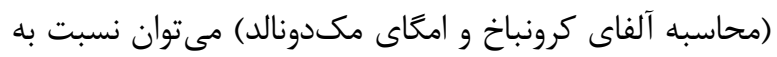
پايايى قابل توجه نسخء فارسى فرم كوتاه پيرسشنامة استرس شغلى يرستاران (NOSS) اطمينان حاصل نمود. در واقع مقايسٔ

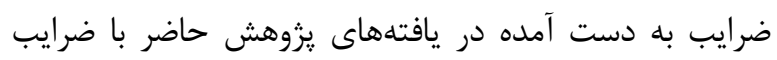

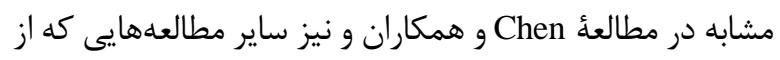
اين يرسشنامه استفاده نمودهاند (همجون

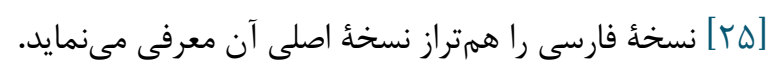

$$
\text { نتيجه گَيرى }
$$

با توجه به مطلوب بودن شاخصهاى روانسنجى، مىتوان نتيجه گرفت كه نسخه فارسى :يرسشنامه استرس شغلى يرستاران (NOSS) براى يرستاران ايرانى، ابزار مناسبى است.

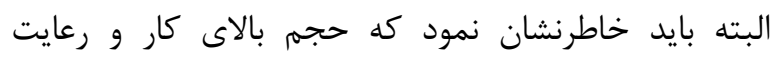
دستورالعملهاى بهداشتى به دشوارى گردآورى اطلاعات ازئن يرستارانى منجر زرديده است كه در مراكز مراقبت از مبتلايان

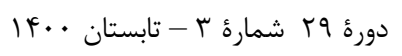

2. Ratnawat R, Jha P. Impact of job related stress on employee performance: a review and research agenda. J Bus Manag. 2014; 16(11):1-6. [DOI:10.9790/487X-161150106]

3. Zamanian Z, Zakian S, Jamali M, Kouhnavard B. Relationship between Safety Culture and Job Stress among the Personnel of Telecom

$$
\text { مجله مراقبت يرستارى و مامايى ابنسينا }
$$


Companies. J Saf Promotion Inj Prev. 2016; 4(3):161-6.

4. Negussie N, Kaur G. The Effect of Job DemandControl-Social Support Model on Nurses' Job Satisfaction in Specialized Teaching Hospitals, Ethiopia. Ethiop J Health Sci. 2016; 26(4):311-20. [DOI:10.4314/ejhs.v26i4.3]

5. World Health Organization. Occupational health: Stress at the workplace. WHO Web Site: 2020 [Accessed on 19 October 2020]. Available from: https://www.who.int/news-room/q-adetail/ccupational-health-stress-at-the-workplace

6. Sharit J, Salvendy G. Occupational stress: review and reappraisal. Hum Fac. 1982; 24(2):129-62. [DOI:10.1177/001872088202400201]

7. Abarghouei MR, Sorbi MH, Abarghouei M, Bidaki R, Yazdanpoor S. A study of job stress and burnout and related factors in the hospital personnel of Iran. Electron Phys. 2016; 8(7):262532. [DOI:10.19082/2625]

8. Dagget T, Molla A, Belachew T. Job related stress among nurses working in Jimma Zone public hospitals, South West Ethiopia: a cross sectional study. BMC Nurs. 2016; 15:39. [DOI:10.1186/s12912-016-0158-2]

9. Ghiyasvandian S, Gebra AA. Coping work strategies and job satisfaction among Iranian nurses. Iran Red Cres Med J. 2014; 16. [DOI:10.5812/ircmj.17779]

10. Hersch RK, Cook RF, Deitz DK, Kaplan S, Hughes D, Friesen MA, et al. Reducing nurses' stress: A randomized controlled trial of a webbased stress management program for nurses. Appl Nurs Res. 2016; 32:18-25. [DOI:10.1016/j.apnr.2016.04.003]

11. Kupcewicz E, Jóźwik M. Positive Orientation and Strategies for Coping with Stress as Predictors of Professional Burnout among Polish Nurses. Int J Enviorn Res Public Health. 2019; 16(21):4264. [DOI:10.3390/ijerph16214264]

12. Khamisa N, Peltzer K, Ilic D, Oldenburg B. Work related stress, burnout, job satisfaction and general health of nurses: A follow-up study. Int J Nurs Pract. 2016; 22(6):538-545. [DOI:10.1111/ijn.12455]

13. Van Bogaert P, Peremans L, Van Heusden D, Verspuy M, Kureckova V, Van de Cruys Z, et al. Predictors of burnout, work engagement and nurse reported job outcomes and quality of care: a mixed method study. BMC Nurs. 2017; 16:5. [DOI:10.1186/s12912-016-0200-4]

14. Mamashli L, Mohammadpour Y, Moghadam A, Esmaeilzadeh S. Examination of the Occupational Stressors among the Nurses Working in Educational Centers in Urmia. Spec J Med Res Health Sci. 2019; 4(1):6-13

15. Mohammadi M, Vaisi-Raygani A, Jalali R, Salari N. Prevalence of Job Stress in Nurses Working in
Iranian Hospitals: A Systematic Review, MetaAnalysis and Meta- Regression Study. J Health Saf Work. 2020; 10(2):119-128. [URL: http://jhsw.tums.ac.ir/article-1-6295-fa.html ]

16. Isfahani $\mathrm{P}$, Arefy $\mathrm{M}$, Peyravi $\mathrm{S}$, Bahador RC, Afshari M. A systematic review and meta-analysis of Job stress among Iranian nurses. Res Square. 2020. [DOI:10.21203/rs.2.24414/v2]

17. Ghanei Gheshlagh R, Parizad N, Dalvand S, Zarei M, Farajzadeh M, Karami M, et al. The prevalence of job stress among nurses in Iran: A meta analysis study. Nurs Midwifery Stud. 2017; 6:143-8. [DOI:10.4103/nms.nms_33_17]

18. Chin WS, Chen YC, Ho JJ, Cheng NY, Wu HC, Shiao JSC. Psychological Work Environment and Suicidal Ideation among Nurses in Taiwan. J Nurs Scholarsh. 2019; 51(1):106-113. [DOI:10.1111/inu.12441]

19. Poursadeghiyan M, Moghimian M, Amjad RN, Baneshi MM, Yari A, Noroozi M, et al. Effects on job stress on Iranian clinical nurses. Ann Trop Med Public Health. 2017; 10:985-8. [DOI:10.4103/ATMPH.ATMPH_306_17]

20. Lee E, Jang I. Nurses' Fatigue, Job Stress, Organizational Culture, and Turnover Intention: A Culture-Work-Health Model. West J Nurs Res. 2020; 42(2):108-116. [DOI: $10.1177 / 0193945919839189]$

21. Deng $X$, Liu X, Fang R. Evaluation of the correlation between job stress and sleep quality in community nurses. Medicine (Baltimore). 2020; 99(4):e18822. [DOI:10.1097/MD.0000000000018822]

22. Starc J. Stress Factors among Nurses at the Primary and Secondary Level of Public Sector Health Care: The Case of Slovenia. Open Access Mac J Med Sci. 2018; 6(2):416-22. [DOI:10.3889/oamjms.2018.100]

23. Lu W, Wang H, Lin Y, Li L. Psychological status of medical workforce during the COVID-19 pandemic: A cross-sectional study. Psych Res. 2020; 288:112936. [DOI:10.1016/i.psychres.2020.112936]

24. Jackson D, Anders R, Padula WV, Daly J, Davidson PM. Vulnerability of nurse and physicians with COVID-19: Monitoring and surveillance needed. J Clin Nurs. 2020; 29(1920):3584-37. [DOI:10.1111/jocn.15347]

25. Xiang YT, Yang Y, Li W, Zhang L, Zhang Q, Cheung T, et al. Timely mental health care for the 2019 novel coronavirus outbreak is urgently needed. Lancet Psych. 2020; 7(3):228-9. [DOI:10.1016/S2215-0366(20)30046-8]

26. Alkhawaldeh JMA, Soh KL, Mukhtar FBM, Ooi $\mathrm{CP}$. Effectiveness of stress management interventional programme on occupational stress for nurses: A systematic review. J Nurs Manag. 2020; 28(2):209-20. [DOI:10.1111/jonm.12938]

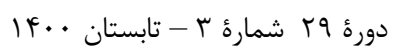


27. Happell B, Dwyer T, Reid-Searl K, Burke KJ, Caperchione CM, Gaskin CJ. Nurses and stress: Recognizing causes and seeking solutions. J Nurs Manag. 2013; 21:638-47 [DOI:10.1111/jonm.12037]

28. Gray-Toft P, Anderson J. The nursing stress scale: Development of an instrument. J Psychopath Behav Assess.1981; 3(1):11-23. [DOI:10.1007/BF01321348]

29. Chen YC, Guo YL, Lin LC, Lee YJ, Hu PY, Ho JJ, et al. Development of the Nurses' Occupational Stressor Scale. Int J Environ Res Public Health. 2020; 17(2):649. [DOI:10.3390/ijerph17020649]
30. Kline RB. Methodology in the Social Sciences. Principles and practice of structural equation modeling (3rd Ed.). Guilford Press; 2011

31. World Health Organization. Process of translation and adaptation of instruments. WHO Web Site; $2006 . \quad$ Available from:[https://www.who.int/substance_abuse/resea rch_tools/translation/en/]

32. Meyers Lawrence S, Glenn Gamst, Guarino AJ. Applied Multivariate Research: Design and Interpretation. Thousand Oaks: Sage; 2006.

33. Hooper D, Coughlan J, Mullen M. Structural Equation Modelling: Guidelines for determining model fit. Electron J Bus Res Methods. 2008; 6(1):53-60. 